\title{
Students' perceptions and satisfaction level of hybrid problem-based learning for 16 years in Kyungpook National University School of Medicine, Korea
}

\author{
Sanghee Yeo and Bong Hyun Chang \\ Department of Medical Education, Kyungpook National University School of Medicine, Daegu, Korea
}

Purpose: Kyungpook National University School of Medicine has been implementing hybrid problem-based learning (PBL) since 1999. The aim of this study was to investigate the changes in the students' perceptions and satisfaction levels of hybrid PBL. Methods: The target period of our study was from 1999 to 2014, and target subjects were second-year medical students in Kyungpook National University School of Medicine. The survey was conducted th the end of semester. We had a focused interview with group leaders and some volunteer students.

Results: As for the scores regarding students' overall satisfaction with PBL, there was significant improvement in 2005 compared to 2002, but the scores decreased and no differences between the survey years noted after 2005. The students' preference ratio for the once a week PBL sessions, tutor presence, synchronization of contents, and arrangement of PBL sessions and related lectures was $60 \%-80 \%, 50 \%-90 \%, 52 \%-96 \%$, and $78 \%-93 \%$, respectively.

Conclusion: In order to increase students' satisfaction with hybrid PBL and to improve the perception of it, firstly, it is necessary to arrange the date and the time of PBL sessions so that students can concentrate on PBL. Secondly, PBL cases should be selected and arranged to be well synchronized with the ongoing lectures. Finally, it is important to create a safe atmosphere so that students can engage actively in PBL sessions.

Key Words: Problem-based learning, Hybrid problem-based learning, Medical education, Medical schools, Learning method

\section{Introduction}

Problem-based Learning (PBL) began to be implemented at some medical schools with innovative curriculum in Asia during the 1970s after Howard Barrows pioneered PBL program at the McMaster University Medical School in the late 1960s [1]. Twenty-three medical schools in Korea have adopted PBL as an experimental or a formal course since the 1990s [2]. The hybrid PBL curriculum of Kyungpook National University School of Medicine (KNUSOM) has been designed to run concurrently with a conventional curriculum over the past decade since it was adopted as a two credits pass/fail course in 1999 [3].

The available reports have involved the principle and practice of PBL [4], development and the application of PBL [5], case reports of implementation or experience of PBL $[3,6,7,8,9,10,11,12]$, its evaluation $[3,7,8,9,13]$, and self-directed learning readiness $[14,15]$. Through these
Received: November 17, 2015 • Revised: December 14, 2015 • Accepted: December 15, 2015 Corresponding Author: Bong Hyun Chang (http://orcid.org/0000-0003-4082-412X) Department of Medical Education, Kyungpook National University School of Medicine, 680 Gukchaebosang-ro, Jung-gu, Daegu 41944, Korea

Tel: +82.53.420.4892 Fax: +82.53.423.1369 email: mededu@knu.ac.kr
Korean J Med Educ 2016 Mar; 28(1): 9-16. http://dx.doi.org/10.3946/kjme.2016.4 eISSN: 2005-7288

(C) The Korean Society of Medical Education. All rights reserved. This is an open-access article distributed under the terms of the Creative Commons Attribution Non-Commercial License (http:// creativecommons.org/licenses/by-nc/3.0/), which permits unrestricted non-commercial use, distribution, and reproduction in any medium, provided the original work is properly cited. 
studies a better understanding and sharing of their experiences of PBL could be promoted. It is still a challenge to the adoption and implementation of PBL with some variations to suit each medical school situation and needs.

This article reports our 16-year experiences of hybrid PBL regarding the level of the students' satisfaction with PBL, the students' preference for the number of PBL sessions per week, the arrangement of PBL sessions and lectures, and the preference for the tutor presence at PBL session. We believe that this study could help medical schools adopt and develop PBL.

\section{Subjects and methods}

\section{Subjects}

Our survey subjects were second year medical students who participated in the PBL curriculum of KNUSOM. The questionnaire was completed by 685 students out of 716 PBL participants (Table 1).
Seven survey topics we categorized were students' overall satisfaction, longitudinal or block style of PBL operations, frequency of PBL sessions, arrangement of PBL case, synchronization of contents, tutor presence, and grading method (Table 2).

\section{Methods}

The questionnaire survey and focused interviews were conducted at the end of the semester. Group leaders and some volunteer students were interviewed using openended questions. The interview was recorded and analyzed with the approval.

The questionnaire was developed using closed-ended items modified from surveys which had been reported in previous studies $[3,4,8,12]$. The internal reliability of the questionnaire items was verified by Cronbach $\alpha$ coefficient. The items were answered using a 5-point Likert scale ( $1=$ strongly disagree to $5=$ strongly agree) in 2002 and 2005. Since 2009, a 7-point scale (1=strongly disagree to $7=$ strongly agree) was used. Different scales used in different years were synchronized into a 5-point scale by a statistics program, so as to be analyzed for

Table 1. Survey Participant

\begin{tabular}{lccccccc}
\hline & 2002 & 2005 & 2009 & 2010 & 2012 & 2014 & Total \\
\hline No. of Participants & 134 & 139 & 110 & 113 & 110 & 110 & 716 \\
No. of Respondents & 127 & 122 & 109 & 113 & 106 & 108 & 684 \\
Responding rate (\%) & 94.8 & 87.8 & 99.0 & 100 & 96.3 & 98.1 & 95.7 \\
\hline
\end{tabular}

Table 2. Topic and Target Year of Survey

\begin{tabular}{|c|c|c|c|c|c|c|}
\hline Survey topic & 2002 & 2005 & 2009 & 2010 & 2012 & 2014 \\
\hline Student's overall satisfaction level & 0 & 0 & 0 & 0 & O & 0 \\
\hline Students' preference between longitudinal style vs. block style & $\bigcirc$ & $\bigcirc$ & & & & \\
\hline Students' preference for frequency of PBL sessions per week & 0 & & 0 & 0 & 0 & 0 \\
\hline Arrangement of PBL session and related lecture & & & $\bigcirc$ & $\bigcirc$ & $\bigcirc$ & \\
\hline Synchronization of contents of PBL case and ongoing lecture & $\bigcirc$ & & $\bigcirc$ & $\bigcirc$ & & \\
\hline Students' preference for tutor attendance at PBL session & & & $\bigcirc$ & $\bigcirc$ & $\bigcirc$ & $\bigcirc$ \\
\hline Students' preference for the grading system & 0 & & 0 & 0 & 0 & 0 \\
\hline
\end{tabular}

PBL: Problem-based learning. 
inter-year variability.

The differences in students' overall satisfaction levels between years were assessed by one-way analysis of variance after extracting the same five items from the annual PBL questionnaire (Table 3). The internal reliability of five items by Cronbach $\alpha$ was 0.631 (in 2002), 0.956 (in 2005), 0.763 (in 2009), 0.627 (in 2010), 0.714 (in 2012), and 0.721 (in 2014). Another frequency and descriptive analysis was also conducted. All data were analyzed with SPSS version 22.0 for Window (SPSS Inc.,
Chicago, USA) and $p<0.05$ was considered significant.

\section{Results}

\section{Students' overall satisfaction levels of PBL}

The mean scores of students' overall satisfaction levels based on a 5-point scale were 3.51 points (in 2002), 4.26 points (in 2005), 3.86 points (in 2010), 3.95 points (in

Table 3. Student's Overall Satisfaction Level of Problem-Based Learning

\begin{tabular}{|c|c|c|c|c|c|c|c|c|}
\hline Survey item & Year & No. & Mean score & SD & SD & $\mathrm{F}$ & $\mathrm{p}$ & Scheffe \\
\hline \multirow{5}{*}{$\begin{array}{l}\text { I am satisfied with the } \\
\text { PBL }\end{array}$} & 2002 (a) & 127 & 3.68 & 0.916 & 0.081 & \multirow[t]{5}{*}{$22.506^{*}$} & \multirow[t]{5}{*}{0.000} & $a<b, d$ \\
\hline & 2005 (b) & 122 & 4.26 & 0.557 & 0.050 & & & $b>c, e$ \\
\hline & 2010 (c) & 113 & 3.88 & 0.530 & 0.050 & & & $c>e$ \\
\hline & 2012 (d) & 106 & 4.05 & 0.653 & 0.063 & & & $d>e$ \\
\hline & 2014 (e) & 108 & 3.44 & 0.835 & 0.080 & & & \\
\hline \multirow{5}{*}{$\begin{array}{l}\text { I am satisfied with my } \\
\text { tutor }\end{array}$} & 2002 (a) & 127 & 3.31 & 0.870 & 0.077 & \multirow[t]{5}{*}{$28.305^{*}$} & \multirow[t]{5}{*}{0.000} & $a<b, d$ \\
\hline & 2005 (b) & 122 & 4.25 & 0.621 & 0.056 & & & $b>c, d, e$ \\
\hline & 2010 (c) & 113 & 3.31 & 0.791 & 0.074 & & & $c<d$ \\
\hline & 2012 (d) & 106 & 3.65 & 0.829 & 0.080 & & & \\
\hline & 2014 (e) & 108 & 3.62 & 0.817 & 0.079 & & & \\
\hline \multirow{5}{*}{$\begin{array}{l}\text { I am very active in PBL } \\
\text { sessions }\end{array}$} & 2002 (a) & 127 & 3.81 & 0.710 & 0.063 & \multirow[t]{5}{*}{$9.485^{*}$} & \multirow[t]{5}{*}{0.000} & $a<b, e$ \\
\hline & 2005 (b) & 122 & 4.30 & 0.585 & 0.053 & & & \\
\hline & 2010 (c) & 113 & 4.04 & 0.557 & 0.052 & & & \\
\hline & 2012 (d) & 106 & 4.06 & 0.659 & 0.064 & & & \\
\hline & 2014 (e) & 108 & 4.14 & 0.648 & 0.062 & & & \\
\hline \multirow{5}{*}{$\begin{array}{l}\text { I do self-directed } \\
\text { learning for PBL }\end{array}$} & 2002 (a) & 127 & 3.33 & 0.713 & 0.063 & \multirow[t]{5}{*}{$28.786^{*}$} & \multirow[t]{5}{*}{0.000} & $a<b, c, d, e$ \\
\hline & 2005 (b) & 122 & 4.23 & 0.614 & 0.056 & & & $b>c, d, e$ \\
\hline & 2010 (c) & 113 & 3.75 & 0.675 & 0.064 & & & \\
\hline & 2012 (d) & 106 & 3.90 & 0.661 & 0.064 & & & \\
\hline & 2014 (e) & 108 & 3.92 & 0.725 & 0.070 & & & \\
\hline \multirow{5}{*}{$\begin{array}{l}\text { Team members are } \\
\text { cooperative and } \\
\text { helpful for each } \\
\text { other }\end{array}$} & 2002 (a) & 127 & 3.42 & 0.771 & 0.068 & \multirow[t]{5}{*}{$38.837^{*}$} & \multirow[t]{5}{*}{0.000} & $a<b, c, d, e$ \\
\hline & 2005 (b) & 122 & 4.27 & 0.499 & 0.045 & & & \\
\hline & 2010 (c) & 113 & 4.31 & 0.568 & 0.053 & & & \\
\hline & 2012 (d) & 106 & 4.08 & 0.643 & 0.062 & & & \\
\hline & 2014 (e) & 108 & 4.06 & 0.681 & 0.066 & & & \\
\hline \multirow{5}{*}{$\begin{array}{l}\text { Total of above five } \\
\text { items }\end{array}$} & 2002 (a) & 127 & 3.51 & 0.509 & 0.045 & \multirow[t]{5}{*}{$42.452^{*}$} & \multirow[t]{5}{*}{0.000} & $a<b, c, d, e$ \\
\hline & 2005 (b) & 122 & 4.26 & 0.405 & 0.037 & & & $b>c, d, e$ \\
\hline & 2010 (c) & 113 & 3.86 & 0.393 & 0.037 & & & \\
\hline & 2012 (d) & 106 & 3.95 & 0.462 & 0.045 & & & \\
\hline & 2014 (e) & 108 & 3.84 & 0.512 & 0.049 & & & \\
\hline
\end{tabular}

SD: Standard deviation, PBL: Problem-based learning. ${ }^{*} \mathrm{p}<0.05$. 
2012), and 3.84 points (in 2014). A significant improvement was noted in 2005 compared to 2002 but the score decreased significantly after 2005 (Table 3, Fig. 1).

The mean scores of the first item ("I am satisfied with PBL") in 2002, in 2005, in 2010, in 2012, in 2014 were 3.68 points, 4.26 points, 3.88 points, 4.05 points, and 3.44 points, respectively. The score of 2005 was significantly higher than that of 2002 but the score decreased significantly in 2010 and in 2014 (Table 3, Fig. 1).

The mean scores of the second item ("I am satisfied with my tutor") in 2002, in 2005, in 2010, in 2012, in 2014 were 3.31 points, 4.25 points, 3.31 points, 3.65 points, and 3.62 points, respectively. The score of 2005 increased significantly than that of 2002, but after 2005, the score decreased significantly (Table 3, Fig. 1).

The mean scores of the third item ("I am very active in PBL sessions") in 2002, in 2005, in 2010, in 2012, in 2014 were 3.81 points, 4.30 points, 4.04 points, 4.06 points, and 4.14 points, respectively. The score of 2005 was significantly higher than that of 2002. There were no significant differences after 2005 (Table 3, Fig. 1).

The mean scores of the fourth item ("I do self-directed learning for PBL") in 2002, in 2005, in 2010, in 2012, in 2014 were 3.33 points, 4.23 points, 3.75 points, 3.90 points, and 3.92 points, respectively. The score of 2005 increased significantly than that of 2002, but after 2005, the score became lower significantly (Table 3, Fig. 1).

The mean scores of the fifth item ("Team members are cooperative and helpful for each other") in 2002, in 2005, in 2010, in 2012, in 2014 were 3.42 points, 4.27 points, 4.31 points, 4.08 points, and 4.06 points, respectively. A significant improvement was noted after 2002. There was no significant difference after that (Table 3, Fig. 1).

\section{Students' preference for the style of PBL operations: longitudinal versus block}

In the 2002 and 2005 survey, approximately $70 \%$ of students preferred "the longitudinal" to "the block." Many students were prone to spent time in reviewing lecture materials and preparing for their exams during the block PBL period. Therefore the block style was replaced by the longitudinal PBL.

\section{Students' preference for the frequency of PBL sessions per week}

Approximately $60 \%$ to $80 \%$ of students preferred to meet once a week: $63.4 \%$ in 2009, $79.1 \%$ in $2010,65.1 \%$ in 2012, and $57.0 \%$ in 2014. Only $2 \%$ to $10 \%$ students

Fig. 1. Student's Overall Satisfaction Level of Problem-Based Learning

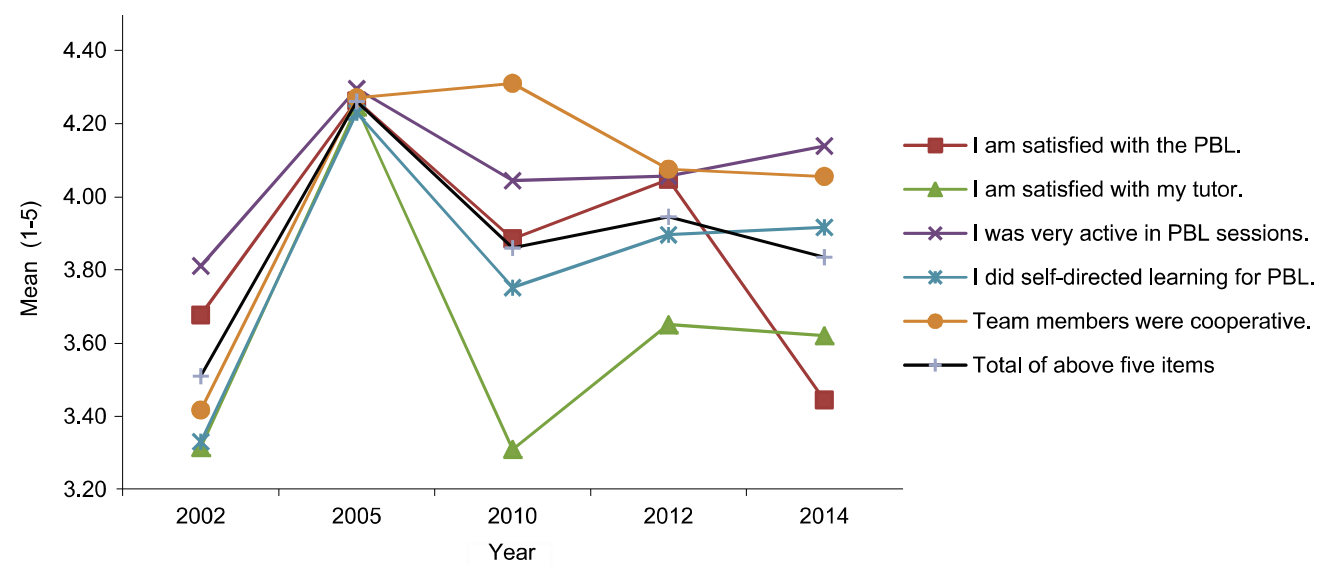

PBL: Problem-based learning. 
preferred to meet twice week.

\section{Arrangement of $\mathrm{PBL}$ session and related lecture: before or after lectures}

Approximately $78 \%$ to $93 \%$ of students preferred to have PBL sessions after related lectures: $78.0 \%$ in 2009, $88.7 \%$ in 2010 , and $92.5 \%$ in 2012.

\section{Synchronization of contents of PBL case and ongoing lecture: dependent versus independent}

Approximately $52 \%$ to $96 \%$ of students showed a preference for using the PBL case well correlated with the contents of concurrent lectures: $95.9 \%$ in 2002, $52.3 \%$ in 2009 , and $64.3 \%$ in 2010 .

\section{Students' preference for having a tutor at PBL session: with tutor versus without tutor}

Approximately $50 \%$ to $91 \%$ of students preferred the presence of a tutor in the group: $54.1 \%$ in 2009 , $49.6 \%$ in 2010, $90.6 \%$ in 2012, and $80.4 \%$ in 2014. Students who preferred to have a tutor asserted that the presence of a tutor itself could create a better learning environment. On the other hand, many students claimed that they had

Table 4. Student's Perception toward Tutor Attendance at Problem-Based Learning Session

\begin{tabular}{|c|c|}
\hline Positive & Negative \\
\hline $\begin{array}{l}\text { - Tutors guide discussion and prevent from going to the wrong } \\
\text { direction. } \\
\text { - Tutors help students understand key points with proper advice } \\
\text { or information. } \\
\text { - Tutors facilitate keeping track of the PBL process by proper } \\
\text { intervention. } \\
\text { - Tutors assist students to approach the issues schematically. } \\
\text { - Tutors help students have organized wrap-up of discussion. }\end{array}$ & $\begin{array}{l}\text { - Discussion is often interrupted by improper tutor intervention. } \\
\text { - Conflicts over the PBL process often caused by the frequent } \\
\text { changes and different facilitation skills of tutors. } \\
\text { - Tutors sometimes fail to guide the right direction and session } \\
\text { becomes distracted. } \\
\text { - Students often hesitate to talk in front of tutors or are } \\
\text { intimidated by tutors. } \\
\text { - Tutors are sometimes too aggressive in questioning and make } \\
\text { students embarrassed and helpless. }\end{array}$ \\
\hline
\end{tabular}

PBL: Problem-based learning.

Table 5. Tools for Student Assessment in Problem-Based Learning

\begin{tabular}{ccccccccc}
\hline Year & $\begin{array}{c}\text { Tutor } \\
\text { assessment }\end{array}$ & $\begin{array}{c}\text { Learning } \\
\text { report }\end{array}$ & MEQ & $\begin{array}{c}\text { Peer } \\
\text { assessment }\end{array}$ & $\begin{array}{c}\text { Responding } \\
\text { questionnaire }\end{array}$ & $\begin{array}{c}\text { Case } \\
\text { mapping }\end{array}$ & Attendance & Others \\
\hline 2002 & 50 & 20 & 20 & - & 10 & - & - & - \\
2003 & - & 30 & 50 & - & 10 & - & - & 10 \\
2004 & 50 & 30 & - & - & 10 & - & - & 10 \\
2005 & 50 & 40 & - & - & 10 & - & - & - \\
2006 & 50 & - & 10 & 10 & - & 10 & 10 & 10 \\
2007 & 50 & 30 & - & - & 10 & 10 & - & - \\
2008 & 50 & 30 & - & - & 10 & 10 & - & - \\
2009 & 50 & - & 10 & 10 & 10 & 10 & 10 & - \\
2010 & 50 & - & 10 & - & 10 & 10 & 20 & - \\
2011 & 40 & - & 10 & - & 10 & 20 & 20 & - \\
2012 & 40 & - & 10 & - & 10 & 20 & 20 & - \\
2013 & 40 & - & 10 & - & 10 & 20 & 20 & - \\
2014 & 40 & - & 10 & - & 10 & 20 & 20 & - \\
\hline
\end{tabular}

Data are presented as percentage.

MEQ: Modified essay question. 
experienced unsafe atmosphere, difficulty in adjusting to different PBL facilitation skills of tutors due to the insufficient standardization of tutor (Table 4).

\section{Students' preference for the grading system: pass/fail versus grading}

The tools for student assessment consisted of tutor assessment, learning report, modified essay questions (MEQs), peer assessment, responding questionnaire, drawing case mapping and schema, and attendance (Table 5). Approximately $49 \%$ to $94 \%$ of students were in favor of pass/fail system over a grading system: $48.5 \%$ in $2002,93.6 \%$ in $2009,93.6 \%$ in $2010,93.6 \%$ in 2012 , and $89.7 \%$ in 2014. Regarding peer assessment, students disclosed that they gave the same score to each other in most cases. Therefore, peer assessment proved not to serve as a reliable assessment tool.

\section{Discussion}

We define the PBL run concurrently with a lecturebased traditional curriculum as hybrid PBL in this article. The analysis of the changes in the students' perceptions and satisfaction levels of 16-year hybrid PBL showed that students preferred once-a-week PBL to twice or more PBL per week throughout the semester. This can be interpreted as a way of means for students to choose to lessen the burdens on hybrid PBL at a medical school. Kim et al. [5] also mentioned that when a medical school introduces PBL in a traditional curriculum, it is desirable to impose the least amount of burden on students.

Our results showed that most students preferred the contents of the PBL case to be synchronized with ongoing lectures, and the case to be studied after the related lectures. The possible explanation of preference is that students want to reduce the time and efforts required to study the PBL case and want to be activated the discussion during the PBL session using the knowledge they have learned in previous lectures.

In our study, the students' opinions on the tutor presence were widely distributed (approximately 50\%96\%). Students appeared to welcome a tutor who could understand the philosophy and process of the PBL. Park et al. [11] reported that students evaluated the role of tutor as somewhat negative and good facilitation skills of discussion and process of the PBL is strongly required. Hur \& Kim [16] reported that the discussion was often interrupted by improper tutor intervention and the important role of tutors was to facilitate open discussion and to create a safe environment. According to Nanda \& Manjunatha [17], tutors who are too strict could generate stress and pressure among students and an uncomfortable atmosphere can disrupt students' open-minded thought. There is no need for tutor in a PBL session if the tutor is too strict. For this reason, investigators claim that tutors need more training to conduct the PBL. These studies support our results of the students' preference for having a tutor and students' perceptions toward tutor.

In our study, the tools for assessment included tutor and peer assessment, learning report, MEQs, responding questionnaire, drawing case mapping and schema, and attendance. Our results revealed that peer assessment proved not to serve as a reliable assessment tool. According to Kim et al. [18], peer assessment could be used as an effective assessment tool for students' performance in PBL when peer evaluation score is not included in the grades. User-friendly peer evaluation can be used to screen for maladjusted students when students understand the purpose and feedback method of peer assessment well and the questionnaire of peer review is well constituted. Most of the students in our school preferred the pass/fail assessment to grading after 
2002. The result regarding preference for grading is consistent with that of Chung et al. [12].

In summary, our results indicate that in order to increase students' satisfaction with hybrid PBL and to improve the perception of it, firstly, it appears to be necessary to arrange the date and the time of PBL sessions so that students can concentrate on PBL. Secondly, PBL cases should be selected and arranged to be well synchronized with the concurrent lectures. Finally, it is important to create a safe atmosphere so that students can engage actively in PBL sessions. It is strongly recommended that the tutor should play a role to facilitate the group's thinking and discussion and to guide the PBL process.

Acknowledgements: None.

Funding: This research was supported by Kyungpook National University Research Funds, 2012.

Conflicts of interest: None.

\section{References}

1. Barrows HS. Problem-based learning applied to medical education. Springfield, USA; Southern Illinois University School of Medicine; 2000.

2. Korean Association of Medical College. The report of medical college education: 2005-2006. Vol. 14. Seoul, Korea: Korean Association of Medical College; 2009.

3. Chang BH, Lee YC, Kim BW, Kang DS, Kwak YS, Kang E, Seo KS, Kim IK, Lee JM, Jeong SH, Kim JY, Kim IS, Kim HJ. The implementation of problem-based learning in Kyungpook National University School of Medicine and its evaluation. Korean J Med Educ 2001; 13: 91-105.

4. Kim YJ, Kang PS, Lee CK, Park JH. The principle and practice of PBL. Korean J Med Educ 2000; 12: 1-14.
5. Kim S, Yang EB, Lee SK, Kang HC, Lee MS. The development and the application of problem-based learning curriculum. Korean J Med Educ 1998; 10: 309-321.

6. Eun HC, Kim BK, Kim JG, Baik SH. Comparative study of problem-based learning (PBL) experiences in different learning groups. Korean J Med Educ 1997; 9: 119-128.

7. Lee JT, Choi JS, Kim SH, Paik NW. the experience and evaluation of problem-based learning in Inje University College of Medicine. Korean J Med Educ 1998; 10: 351-362.

8. Kim JJ, Lee KJ, Won JH, Lee DH, Ahn ET. PBL practice and its evaluation in Soonchunhyang Medical School. J Soonchunhyang Med Coll 2002; 8: 39-47.

9. So YH, Lee YM, Ahn DS. An student's evaluation of the implementation of problem-based learning. Korean J Med Educ 2005; 17: 49-58.

10. Chae SJ, Lee DS, Lee YS. Causal analysis and improvement strategies of the problems in implementing a pbl program in integrated curriculum. Korean J Med Educ 2003; 15: 35-43.

11. Park EH, Park JH, Park YN. The experience of problembased learning in Keimyung University College of Medicine. Korean J Med Educ 2000; 12: 261-270.

12. Chung IW, Shin CJ, Hahn HS, Song YJ. The practice and evaluation of problem-based learning in College of Medicine, Chungbuk National University. Korean J Med Educ 1999; 11: 285-295.

13. Kim JH, Kim JY, Son HJ, Choi YH, Hong KP, Ahn BH, Uhm DY, Chin YE, Seo JD. A qualitative evaluation of problem-based learning curriculum by students' perceptions. Korean J Med Educ 2004; 16: 179-193.

14. Chae SJ, Shin JS, Lee YS. Comparison of the academic achievement by self-directed learning readiness levels in a hybrid problem based learning course. Korean J Med Educ 2004; 16: 281-288.

15. Yune SJ, Im SJ, Lee SH, Baek SY, Lee SY. Effects of 
differences in problem-based learning course length on academic motivation and self-directed learning readiness in medical school students. Korean J Med Educ 2010; 22: 23-31.

16. Hur Y, Kim S. Teaching and learning strategies of PBL. Korean J Med Educ 2002; 14: 145-156.

17. Nanda B, Manjunatha S. Indian medical students' perspectives on problem-based learning experiences in the undergraduate curriculum: one size does not fit all. J Educ Eval Health Prof 2013; 10: 11.

18. Kim JY, Son HJ, Lee JH, Kim JH, Hong KP. Educational implication of peer evaluation in problem-based learning. Korean J Med Educ 2005; 17: 275-284. 